$\xi=1$ -

\title{
Optimization of Machining Characteristics of Hybrid Composites Using Grey Relational Technique
}

\author{
Ramanan.G', Neela Rajan.R.R ${ }^{2}$, Jai Aultrin.K.S ${ }^{2}$, Pradeep.P ${ }^{2}$ \\ ${ }^{1}$ Department of Aerospace Engineering, ACS College of Engineering, Bangalore, \\ Karnataka, India-560074 \\ ${ }^{2}$ Department of Aeronautical Engineering, Noorul Islam Centre for Higher Education, Kumaracoil, \\ Tamilnadu, India-629180
}

\begin{abstract}
Metal matrix composite imparts several advantages over alloys. The MMCs exhibit improved properties compared with monolithic alloy. They are particularly suited for applications that require higher strength, dimensional stability and enhanced structural rigidity. Aluminium composite materials are engineered materials made from at least two or more constituent materials having different physical or chemical properties. In this work Seventeen turning experiments were conducted using response surface methodology. The machining parameters cutting speed, feed rate, and depth of cut are varied with respect to different machining conditions for each run. The optimal parameters were predicted by grey relational analysis technique. The optimum process parameter predicted from RSM techniques is cutting speed $250 \mathrm{~m} / \mathrm{min}$, feed rate $0.06 \mathrm{~mm}$ and depth of cut $1.5 \mathrm{~mm}$ are found.
\end{abstract}

Keyword: Aluminium composites, Grey relational analysis, surface roughness

\section{Introduction}

Light weight metal matrix composite (MMC) imparts several advantages over alloys. The MMCs exhibit improved properties compared with monolithic alloy. They are particularly suited for applications that require higher strength, dimensional stability and enhanced structural rigidity [1]. Composite materials are engineered materials made from at least two or more constituent materials having different physical or chemical properties. In short, the composite materials are multi-functional systems that exhibit characteristics from all the individual components [2]. Aluminum based MMCs are the widely used matrix materials for MMCs. It was identified as conventional materials that can be used for several commercial and industrial applications. The reduction in the gross-weight of a component can reduce the fuel consumption and thereby reduce the dependence over fossil fuels [3]. It helps to reduce the emission of greenhouse gases and thereby keeps the pollution under control. Replacing conventionally used material with MMCs can improve the fuel economy and can enhance the engine aspiration. The commercial exploitation of MMC is now becoming significant [4]. Literatures reported that just lowering the body weight without reducing the weight of the power train would not alter the fuel economy. Such that to enhance the fuel economy the engine material has to be replaced with lighter materials [5]. Though Al-based MMCs in automobiles enhances the efficiency of the engine, the higher processing cost does not recommend its usage over the steel counter parts. However, dramatic energy saving was observed when recycled Al parts were used. This suggests that the energy can be saved through the usage of recycled Al parts [6]. Response Surface Methodology (RSM) has become a very powerful tool in the mathematical modeling of functional-relationships between the output responses and the input variables. Various studies have been carried out based on the prediction of mechanical and wear behavior of composites using RSM [7]. Vettivel et al and Balasubramanian et al analyzed the various modeling methods that can be used to define the desired output variables through the development of mathematical models. The specific wear rate among these response variables characterizes the nature of the $\mathrm{Al}-\mathrm{TiB}_{2}$ composite. Authors have observed that RSM is helpful in developing a suitable approximation for the true functional relationship between the independent variables and the response variable that may characterize the nature of the machining [8]. It has been proved that efficient use of statistical design on experimental techniques allows the development of an empirical methodology to incorporate a scientific approach [9]. Ramanan et al have explained that RSM is a collection of mathematical and statistical techniques, which consist of experimental design for defining the range of independent input variables and empirical mathematical model [10]. The empirical mathematical model is used to explore an appropriate relationship between the output responses and the input variables [10]. Authors developed a numerical model to predict the abrasive wear rate of AA7075 alloy reinforced with SiC particles. Most of researchers observed that RSM provides quantitative measurements for possible interactions between factors so as to obtain difficult information using other optimization techniques. So this research work is planned to predict the optimum parameters between various input parameters for AA7075-TiC metal matrix composites.

\section{Experimental Design}

Experimentation and optimization of cutting parameters are done based on the response surface methodology. CNC turning machine is used for performing the machining operation.

Experimental design is created by Minitab software followed 
by statistical analysis [12]. Statistical studies of computer applications have some advantage like reliable, accurate and usually runs faster than other computing statistics and drawing graphs. Minitab is relatively simple to use when you know some fundamentals. Then performing machining operation on the samples in different cutting environments connecting different grouping of process control parameters. MRR is calculated for the work piece during the machining operation. SR is calculated using a surface roughness profilometer. ANOVA analysis for regression test used to find the significant parameters. The process parameters affecting the turning process machining characteristics is given below. Cutting Speed (A), Feed Rate (B) and Depth of cut (C). In the optimization design involving RSM, the initial task is to create the optimization model, like the system identification measures along with selection of the criteria which influence the scheme determines significantly.

\begin{tabular}{cccccc}
\multicolumn{7}{c}{ Table 1. Variables and levels } \\
\hline Symbol & Cutting Parameter & level 1 & Level 2 & Level 3 & Units \\
\hline A & Cutting speed & 120 & 180 & 250 & $\mathrm{~m} / \mathrm{min}$ \\
B & Feed rate & 0.05 & 0.06 & 0.075 & $\mathrm{~mm}$ \\
C & Depth of Cut & 1 & 1.25 & 1.5 & $\mathrm{~mm}$ \\
\hline
\end{tabular}

Table.2 Design matrix of the experiments with the optimal model data

\begin{tabular}{cccccc}
\hline Experiment & $\begin{array}{c}\text { Cutting } \\
\text { speed }\end{array}$ & Feed & $\begin{array}{c}\text { Depth } \\
\text { of Cut }\end{array}$ & $\begin{array}{c}\text { Material } \\
\text { Removal } \\
\text { Rate }\end{array}$ & $\begin{array}{c}\text { Surface } \\
\text { Roughness }\end{array}$ \\
\hline & $\mathbf{A}$ & $\mathbf{B}$ & $\mathbf{C}$ & $\left(\mathbf{m m}^{3} / \mathbf{m i n}\right)$ & $\mathbf{R a}(\boldsymbol{\mu m})$ \\
1 & 180 & 0.06 & 1.25 & 4.57 & 1.23 \\
2 & 180 & 0.06 & 1.25 & 5.25 & 0.98 \\
3 & 180 & 0.07 & 1.0 & 6.74 & 1.35 \\
4 & 250 & 0.07 & 1.25 & 8.24 & 1.34 \\
5 & 120 & 0.07 & 1.25 & 3.24 & 0.89 \\
6 & 180 & 0.06 & 1.25 & 5.25 & 0.97 \\
7 & 120 & 0.05 & 1.5 & 4.14 & 0.85 \\
8 & 250 & 0.05 & 1.25 & 7.65 & 1.31 \\
9 & 180 & 0.07 & 1.5 & 6.24 & 1.54 \\
10 & 250 & 0.06 & 1.0 & 7.58 & 1.21 \\
11 & 250 & 0.06 & 1.25 & 6.97 & 1.36 \\
12 & 120 & 0.07 & 1.25 & 3.45 & 0.97 \\
13 & 180 & 0.05 & 1.0 & 5.12 & 1.15 \\
14 & 120 & 0.06 & 1.0 & 3.57 & 1.04 \\
15 & 180 & 0.05 & 1.5 & 5.12 & 1.21 \\
16 & 120 & 0.07 & 1.25 & 3.25 & 0.94 \\
17 & 250 & 0.06 & 1.5 & 6.14 & 1.28 \\
\hline
\end{tabular}

Input parameters of turning process were fixed from the machine setting. The tests were performed adapting standard procedure with process parameter depicted in the Table 4.1. In this work a total of 17 tests need to be performed for 3 process parameters at 3 levels. The SR after each test was measured with the surface roughness profilometer SJ301. The observations are presented in the Table 1 which are further studied and analysed. The machining operations were followed as per the design matrix at random for avoiding systematic errors. Adapting RSM with a Box-Behnken design for 3 variables and 3 levels the average number of tests carried out for machining process parameter are fixed.The corresponding MRR and SR recorderd are presented in Table 2.

\section{Modeling and Optimization}

\subsection{Multiple Regression Analysis}

The experimental data is analyzed to create a multi-regression equation. The regression equations are used to generate sufficient data to train the proposed predictive networks along with the experimental data. The dependency of MRR and Ra asinput is developed using the multi-regression equation. The effect of machining parameters on the output variables of MRR and SR for MMC was performed by experiments as explained in Table 2 . Minitab 17.0 version software is used to find the relationship between the input parameters and the output parameters of MRR and
SR. The full quadratic model for MRR and SR is the best and suitable among all models before the backward elimination, as listed in the Table, where $\mathrm{R}^{2}=98.58 \%$ for MRR and $\mathrm{R}^{2}=99.80 \%$ for SR indicates that $98.58 \%$ and $99.80 \%$ of total variation in the responses is elucidated by predictors or factors in the model. However, $\mathrm{R}_{\text {adj }}^{2}$ is $97.44 \%$ for MRR and $99.64 \%$ for $\mathrm{SR}$, which accounts for the number of predictors in the model describe the significance of relationship. Hence, the full quadratic model is regarded for further analysis in the study. ANOVA is used to ensure the sufficiency of second-order model, which comprises test for significance of the regression model, coefficients of the model and test for the lack of fit. MRR and SR summarize the ANOVA of the model that includes two sources of variation, i.e, regression and residual error. The variation due to the terms in the model is the summation of linear and the square terms whereas lack of fit and the pure error contribute to residual error. The p-value of lack of fit is $\leq 0.05$, and certainly indicates that there is statistically significant at $95 \%$ confidence level. However, the p-value of regression model and it's all linear and square terms have $p$-value 0.000 , hence they are statistically significant at $95 \%$ confidence and thus the model adequately represent the experimental data. It is observed that both the experimental values and predicted values using multiple regression models coincide each other and forms a straight line and the experimental values are fit for further analysis.

\section{Grey Relational Analysis}

GRA is considered to optimize particular output typical values. In this section, the use of GRA optimization methodology for multiresponse optimization is discussed. Without large data sets their investigation by statistical procedure are undesirable or reliable. The study implementing typical statistical procedure is unsatisfactory lacking huge data sets. Here, GRA converts the multiple response optimization models into a single response GRA grade. Rather than holding investigational values honestly in multi regression model, grades have been involved to analysis the multi response characteristics. To check the appropriate selection of turning process parameters, GRA are applied. Solution of a system provided by grey theory is that the model is uncertain or the information is unfinished. Beyond, it exhibits a perfect solution to the uncertainty, discrete data and multi-input problem.

\begin{tabular}{|c|c|c|c|c|c|c|}
\hline $\begin{array}{c}\text { Sl. } \\
\text { No } \\
\text {. }\end{array}$ & $\begin{array}{c}\text { MRR } \\
\left(\mathrm{mm}^{3} / \mathrm{mi}\right. \\
\text { n) Exp. } \\
\text { Value }\end{array}$ & $\begin{array}{c}\text { SR } \\
(\mu \mathrm{m}) \\
\text { Exp. } \\
\text { Val- } \\
\text { ue }\end{array}$ & $\begin{array}{c}\text { MRR } \\
\left(\mathrm{mm}^{3} / \mathrm{mi}\right. \\
\mathrm{n}) \\
\text { Predict- } \\
\text { ed Val- } \\
\text { ue }\end{array}$ & $\begin{array}{c}\text { SR } \\
(\mu \mathrm{m}) \\
\text { Predict- } \\
\text { ed Val- } \\
\text { ue }\end{array}$ & $\begin{array}{l}\text { MRR } \\
\text { Error }\end{array}$ & $\begin{array}{c}\text { SR } \\
\text { Error }\end{array}$ \\
\hline 1. & 4.57 & 1.23 & 4.27 & 1.34 & $\begin{array}{c}5.2833612 \\
08\end{array}$ & $\begin{array}{c}5.1624 \\
9\end{array}$ \\
\hline 2. & 5.25 & 0.98 & 5.35 & 0.242 & $\begin{array}{c}4.9317765 \\
32\end{array}$ & $\begin{array}{c}4.1265 \\
4\end{array}$ \\
\hline 3. & 6.74 & 1.35 & 6.54 & 1.24 & $\begin{array}{c}1.1893488 \\
96\end{array}$ & $\begin{array}{c}7.1727 \\
1\end{array}$ \\
\hline 4. & 8.24 & 1.34 & 8.14 & 1.244 & $\begin{array}{c}2.2783425 \\
66\end{array}$ & $\begin{array}{c}5.7838 \\
8\end{array}$ \\
\hline 5. & 3.24 & 0.89 & 3.44 & 0.24 & $\begin{array}{c}9.4622176 \\
65\end{array}$ & $\begin{array}{c}2.8692 \\
1\end{array}$ \\
\hline 6. & 5.25 & 0.97 & 5.12 & 0.24 & $\begin{array}{c}7.5910429 \\
51\end{array}$ & $\begin{array}{c}9.8364 \\
4\end{array}$ \\
\hline 7. & 4.14 & 0.85 & 4.85 & 0.24 & $\begin{array}{c}8.2873604 \\
42\end{array}$ & $\begin{array}{c}3.4633 \\
7\end{array}$ \\
\hline 8. & 7.65 & 1.31 & 7.53 & 1.42 & $\begin{array}{c}4.8447144 \\
76\end{array}$ & $\begin{array}{c}5.2718 \\
3\end{array}$ \\
\hline 9. & 6.24 & 1.54 & 6.34 & 1.42 & $\begin{array}{c}3.3586263 \\
09\end{array}$ & $\begin{array}{c}8.5491 \\
8\end{array}$ \\
\hline 10. & 7.58 & 1.21 & 7.32 & 1.75 & $\begin{array}{c}0.4114287 \\
18\end{array}$ & $\begin{array}{c}2.4034 \\
1\end{array}$ \\
\hline 11. & 6.97 & 1.36 & 6.32 & 1.24 & $\begin{array}{c}5.2849738 \\
91\end{array}$ & $\begin{array}{c}5.5930 \\
3\end{array}$ \\
\hline 12. & 3.45 & 0.97 & 3.25 & 0.24 & 3.0534575 & 9.6970 \\
\hline
\end{tabular}




\begin{tabular}{ccccccc} 
& & & & & 11 & 1 \\
13. & 5.12 & 1.15 & 5.53 & 1.425 & 2.1724140 & 6.0594 \\
& & & 45 & 68 & 5 \\
14. & 3.57 & 1.04 & 3.425 & 1.425 & $\begin{array}{c}7.6537371 \\
88\end{array}$ & $\begin{array}{c}7.5844 \\
2\end{array}$ \\
15. & 5.12 & 1.21 & 5.42 & 1.24 & $\begin{array}{c}3.5050496 \\
32\end{array}$ & $\begin{array}{c}3.1358 \\
7\end{array}$ \\
16. & 3.25 & 0.94 & 3.42 & 0.24 & $\begin{array}{c}0.4759709 \\
87\end{array}$ & $\begin{array}{c}4.9509 \\
7\end{array}$ \\
17. & 6.14 & 1.28 & 6.42 & 1.82 & $\begin{array}{c}7.5571217 \\
7.2992\end{array}$ \\
\hline
\end{tabular}

\subsection{Implementation of GRA}

The below mentioned steps to be followed while GRA to find the grey relational coefficients and the grey relational grade: Normalizing the value of experimental results of MRR and SR to avoid the effect of adopting different units to reduce the changeability.

$$
\begin{aligned}
& Z i j=\frac{y i j-\min (y i j, i=1,2, \ldots \ldots . n)}{\max (y i j, i=1,2, \ldots \ldots . n)-\min (y i j, i=1,2, \ldots \ldots . n)} \\
& Z i j=\frac{\max (y i j, i=1,2, \ldots \ldots n)-y i j}{\max (y i j, i=1,2, \ldots \ldots n)-\min (y i j, i=1,2, \ldots \ldots . n)}
\end{aligned}
$$

Performance of the grey relational generating and calculating the grey coefficient for the normalized values yield.

$$
\gamma(y 0(k), y i(k))=\frac{\Delta \min +\xi \Delta \max }{\Delta 0 j(k)+\xi \Delta \max }
$$

Calculating the grey relational grade by averaging the GRC yields

$$
\gamma \mathrm{j}=\frac{1}{\mathrm{k}} \sum \gamma \mathrm{ij}
$$

Where $\gamma \mathrm{j}$ is the GRG for the $\mathrm{j}^{\text {th }}$ experiment and $\mathrm{k}$ is the number of performance characteristics. To normalize the experimental value, Equation (1) is used, then the original sequence is normalized using Equation (2), i.e., SR is normalized using this Equation. Using Equation (3), to calculate GRA from the experimental data used for MRR and SR. Also GRG is computed as per Equation (4)

\subsection{Identifying the Optimal Parameters}

The Table 4 shows the normalized values of MRR and SR, GRC

\begin{tabular}{|c|c|c|c|c|}
\hline $\begin{array}{l}399974 \\
8\end{array}$ & $\begin{array}{l}30423280 \\
4\end{array}$ & 0.5 & 0.45869081 & 9924 \\
\hline 0.28421251 & 0.54497354 & 0.333356556 & 0.57446808 & 0.51660064 \\
\hline $\begin{array}{c}4 \\
0306769\end{array}$ & $\begin{array}{c}5 \\
0.25925925\end{array}$ & & $\begin{array}{c}5 \\
0.33333333\end{array}$ & $\begin{array}{c}5 \\
0.39870550\end{array}$ \\
\hline 1 & 9 & 0.532259595 & 3 & 2 \\
\hline $\begin{array}{c}0.23225901 \\
2\end{array}$ & $\begin{array}{c}0.83597883 \\
6\end{array}$ & 0.46675959 & $\begin{array}{c}0.65853658 \\
5\end{array}$ & $\begin{array}{c}0.65311653 \\
1\end{array}$ \\
\hline 37551407 & 0.74074074 & 0491759595 & 0.47368421 & 0.48022296 \\
\hline 9 & 1 & & 1 & 1 \\
\hline $\begin{array}{c}0.45315057 \\
3\end{array}$ & $\begin{array}{c}0.78835978 \\
8\end{array}$ & 0.829854545 & 1 & $\begin{array}{c}0.87697160 \\
9\end{array}$ \\
\hline 0.32000398 & 0.41269841 & .54 & 0.52941176 & 0.44440513 \\
\hline 7 & 3 & 5 & 5 & 0 \\
\hline 0.15000104 & 0.14285714 & 0.570459559 & 0.55102040 & 0.58270814 \\
\hline
\end{tabular}
of MRR and SR and grade for MMC.

Table 4. Grade for AA7075-TiC MMC

\begin{tabular}{|c|c|c|c|c|c|}
\hline $\begin{array}{l}\mathbf{N} \\
\text { o. }\end{array}$ & $\begin{array}{l}\text { Material Re- } \\
\text { moval Rate }\end{array}$ & $\begin{array}{c}\text { Surface } \\
\text { Roughness }\end{array}$ & $\begin{array}{c}\text { Investiga- } \\
\text { tional } \\
\text { Grade }\end{array}$ & $\begin{array}{c}\text { Expec } \\
\text { pec- } \\
\text { ted } \\
\text { Grad } \\
\text { e } \\
\end{array}$ & $\begin{array}{c}\text { Pro- } \\
\text { portion } \\
\text { Devia- } \\
\text { tion }\end{array}$ \\
\hline 1. & 4.57 & 1.23 & $\begin{array}{c}0.5635474 \\
53\end{array}$ & $\begin{array}{c}0.790 \\
053\end{array}$ & $\begin{array}{c}10.689 \\
6\end{array}$ \\
\hline 2. & 5.25 & 0.98 & $\begin{array}{c}0.8461538 \\
46\end{array}$ & $\begin{array}{c}0.475 \\
281\end{array}$ & $\begin{array}{c}1.6363 \\
76\end{array}$ \\
\hline 3. & 6.74 & 1.35 & $\begin{array}{c}0.5828690 \\
81\end{array}$ & $\begin{array}{c}0.541 \\
245\end{array}$ & $\begin{array}{c}6.1544 \\
2\end{array}$ \\
\hline 4. & 8.24 & 1.34 & $\begin{array}{c}0.5405613 \\
88\end{array}$ & $\begin{array}{c}0.575 \\
607\end{array}$ & $\begin{array}{c}1.5998 \\
45\end{array}$ \\
\hline 5. & 3.24 & 0.89 & $\begin{array}{c}0.4849984 \\
21\end{array}$ & $\begin{array}{c}0.375 \\
654\end{array}$ & $\begin{array}{c}3.2093 \\
53\end{array}$ \\
\hline 6. & 5.25 & 0.97 & $\begin{array}{c}0.4077380 \\
95\end{array}$ & $\begin{array}{c}0.491 \\
076\end{array}$ & $\begin{array}{c}3.3509 \\
73\end{array}$ \\
\hline 7. & 4.14 & 0.85 & $\begin{array}{c}0.4949605 \\
53\end{array}$ & $\begin{array}{c}0.813 \\
284\end{array}$ & $\begin{array}{c}5.3567 \\
73\end{array}$ \\
\hline 8. & 7.65 & 1.31 & $\begin{array}{c}0.4425219 \\
68\end{array}$ & $\begin{array}{c}0.415 \\
571\end{array}$ & $\begin{array}{c}7.1592 \\
06\end{array}$ \\
\hline 9. & 6.24 & 1.54 & $\begin{array}{c}0.4735474 \\
53\end{array}$ & $\begin{array}{c}0.425 \\
098\end{array}$ & $\begin{array}{c}10.785 \\
22\end{array}$ \\
\hline 10 & 7.58 & 1.21 & $\begin{array}{c}0.6092443 \\
73\end{array}$ & $\begin{array}{c}0.383 \\
585\end{array}$ & $\begin{array}{c}2.2980 \\
46\end{array}$ \\
\hline 11 & 6.97 & 1.36 & $\begin{array}{c}0.5166006 \\
45\end{array}$ & $\begin{array}{c}0.558 \\
063\end{array}$ & $\begin{array}{c}0.0056 \\
19\end{array}$ \\
\hline 12 & 3.45 & 0.97 & $\begin{array}{c}0.3987055 \\
02\end{array}$ & $\begin{array}{c}0.747 \\
760\end{array}$ & $\begin{array}{c}0.5303 \\
12\end{array}$ \\
\hline 13 & 5.12 & 1.15 & $\begin{array}{c}0.6531165 \\
31\end{array}$ & $\begin{array}{c}0.547 \\
956\end{array}$ & $\begin{array}{c}3.6739 \\
15\end{array}$ \\
\hline 14 & 3.57 & 1.04 & $\begin{array}{c}0.4802229 \\
61\end{array}$ & $\begin{array}{c}0.491 \\
076\end{array}$ & $\begin{array}{c}0.8288 \\
74\end{array}$ \\
\hline 15 & 5.12 & 1.21 & $\begin{array}{c}0.8769716 \\
09\end{array}$ & $\begin{array}{c}0.508 \\
184\end{array}$ & $\begin{array}{c}11.362 \\
48\end{array}$ \\
\hline 16 & 3.25 & 0.94 & $\begin{array}{c}0.4444051 \\
30\end{array}$ & $\begin{array}{c}0.534 \\
094\end{array}$ & $\begin{array}{c}7.7222 \\
55\end{array}$ \\
\hline 17 & 6.14 & 1.28 & $\begin{array}{c}0.5827081 \\
48\end{array}$ & $\begin{array}{c}0.740 \\
610\end{array}$ & $\begin{array}{c}4.2525 \\
53\end{array}$ \\
\hline
\end{tabular}

\begin{tabular}{ccccc}
\hline $\begin{array}{c}\text { Normal- } \\
\text { ized for } \\
\text { MRR }\end{array}$ & $\begin{array}{c}\text { Normal- } \\
\text { ized for SR }\end{array}$ & $\begin{array}{c}\text { GRC for } \\
\text { MRR }\end{array}$ & $\begin{array}{c}\text { GRC for } \\
\text { SR }\end{array}$ & Grade \\
\hline 0.15000104 & 0 & 0.45875622 & 0.45762711 & 0.56354745 \\
9 & 0 & 9 & 3 \\
0.41379726 & 0.78835978 & 0.464026265 & 0.69230769 & 0.84615384 \\
4 & 8 & & 2 & 6 \\
0.32000398 & 0.71957672 & 0.647662655 & 0.5 & 0.58286908 \\
7 & & & 0.41538461 & 0.54056138 \\
0.26667086 & 0.53968254 & 0.486732612 & 5 & 8 \\
3 & & 0.39130434 & 0.48499842 \\
0.86399974 & 0.88359788 & 1 & 8 & 1 \\
8 & 4 & & 0.48214285 & 0.40773809 \\
0.32000398 & 0.73015873 & 0.359365494 & 7 & 5 \\
7 & & & 0.45762711 & 0.49496055 \\
0 & 0.19576719 & 0.614395445 & 9 & 3 \\
0.41379726 & 0.93650793 & 0.665759454 & 0.47368421 & 0.44252196 \\
4 & 7 & 1 & 8 \\
0.81259704 & 0.79365079 & 0.665765515 & 0.65762711 & 0.47354745 \\
6 & 4 & & 9 & 3 \\
\hline
\end{tabular}

Table 5. Proportion Deviation of Experimental and Predicted Grade

The comparison among the investigational grade values and expected grade values and percentage deviation between them are depicted in Table 5.

From the grade results the main effect on cutting speed is increases in grade result in high velocity of turning those impacts on the material increases the MRR and produces good SR. From the grey relational grade plot shown in Table 7, the optimal design is identified and then the optimal design is verified by means of confirmation test.

Table 6. Analysis of Variance for Grade for MMC

\begin{tabular}{ccccccc}
\hline Source & DF $^{\mathbf{a}}$ & SeqSS $^{\mathbf{b}}$ & AdjSS $^{\mathbf{d}}$ & Adj $\mathbf{~ M S ~}^{\mathbf{c}}$ & $\mathbf{F}$ & P value $^{\text {(n) }}$ \\
\hline A & 2 & 0.014 & 0.007 & 0.003 & 0.6 & 0.52 \\
B & 2 & 0.054 & 0.005 & 0.002 & 0.4 & 0.65 \\
C & 2 & 0.041 & 0.057 & 0.028 & 5.0 & 0.01 \\
Error & 18 & 0.021 & 0.010 & 0.005 & & \\
Total & 26 & 0.416 & & & & \\
\hline
\end{tabular}


Table 7. Response Table for Grey Relation Grade

\begin{tabular}{cccccc}
\hline Symbol & level 1 & level 2 & level 3 & $\begin{array}{c}\text { Main } \\
\text { effect }\end{array}$ & Rank \\
\hline A & 0.5887 & 0.5541 & 0.3533 & 0.23541 & 2 \\
B & 0.4746 & 0.5457 & 0.6274 & 0.15274 & 3 \\
C & 0.7477 & 0.5338 & 0.4603 & 0.28739 & 1 \\
\hline
\end{tabular}

Confirmation test is used to prove the accuracy of the developed model after identifying the optimal design. The experimental result which is having the high grade value using the initial arrangement of the cutting parameters is compared with the optimal one. Then the experiment is done with the new optimal design for MRR and SR and from Table 8 , it is observed that the MRR increases from $7.65 \mathrm{~mm}^{3} / \mathrm{min}$ to $1.31 \mathrm{~mm}^{3} / \mathrm{min}$ and $\mathrm{SR}$ decreases from $1.31 \mu \mathrm{m}$ to $1.28 \mu \mathrm{m}$ in the optimal combination of cutting parameters.

Table 8. Result of GRA Confirmation Test for MMC

\begin{tabular}{cccccc}
\hline Design & \multicolumn{5}{c}{ Output Parameters } \\
\cline { 2 - 6 } & speed & Feed & $\begin{array}{c}\text { Depth of } \\
\text { Cut }\end{array}$ & $\begin{array}{c}\text { MRR } \\
\left(\mathbf{m m}^{\mathbf{3}} / \mathbf{m i n}\right)\end{array}$ & $\begin{array}{c}\text { SR } \\
(\boldsymbol{\mu m})\end{array}$ \\
\hline $\begin{array}{c}\text { Initial } \\
\text { Design } \\
\text { GRA }\end{array}$ & 250 & 0.05 & 1.25 & 6.14 & 1.31 \\
$\begin{array}{c}\text { Optimal } \\
\text { Design }\end{array}$ & 250 & 0.06 & 1.5 & 7.65 & 1.28 \\
\hline
\end{tabular}

[9] Ramanan.G, Edwin Raja Dhas.J, Ramachandran.M, Optimization of material removal rate and surface roughness for wire electric discharge machining of AA7075 composites using grey relational analysis, International Journal of Vehicle Structures and Systems, 9, 2017, pp. 309-312

[10] Rajesh Prabha.N, Edwin Raja Dhas.J and Ramanan.G., Finite element structural analysis of connecting rod of AA7075-TiC composite using ANSYS, International Journal of Mechanical Engineering and Technology, 8, 2017, pp. 1102-1110.

[11] M. Ramachandran, Back Propagation Neural Network for Prediction of Some Shell Moulding Parameters, Periodica Polytechnica Mechanical Engineering, 60(4), pp. 203-208, 2016.

[12] Ramanan.G, Edwin Raja Dhas, J. Multi Objective Optimization of Wire EDM Machining Parameters for AA7075-PAC Composite Using Grey - Fuzzy Technique, Materials Today Proceedings, Vol.5, No.1, 2018, pp.8280-8289.

[13] K. S. Jai Aultrin, M. Dev Anand, Optimization of Machining Parameters in AWJM Process for Lead Tin Alloy Using RSM and Regression Analysis, International Review of Mechanical Engineering, 9, 2015.

[14] S.Baskaran, V. Anandakrishnan, Investigations on dry sliding wear behavior of casted AA7075-TiC metal matrix composites by taguchi technique, Materials and Design, 60, 2014, pp.184-192.

\section{Conclusion}

In this work machining process is done by response surface methodology design of experiment. The optimal parameters were predicted by GRA technique. However these techniques concentrated on achieving a single quality characteristic at a time as a function of different appropriate levels of a number of input parameter settings. Improving one particular quality characteristic would possible lead to serious degradation of the quality characteristics. The optimal process parameter is predicted from GRA technique is $250 \mathrm{~m} / \mathrm{min}, 0.06 \mathrm{~mm}, 1.5 \mathrm{~mm}$ and responses are influencing process parameters.

\section{References}

[1] Lin ZC, Ho CY, Analysis and application of grey relation and ANOVA in chemical-mechanical polishing process parameters. Int $J$ Adv Manuf Technlogy, 21, 2003, pp.10-14.

[2] W.H. Yang, Y.S. Tang, Design optimization of cutting parameters for turning operations based on Taguchi method, Journal of Materials Processing Technology, 84, 1998, pp.122-129.

[3] Yan BH, Wang CC, Chow HM, Lin YC, Feasibility study of rotary electrical discharge machining with ball burnishing for Al2O3/6061Al composite. Int J Mach Tools Manufacture, 40, 2000, pp.1403-1421.

[4] Ersan Aslan, Necip Camuscu Burak Bingoren, Design of optimization of cutting parameters when turning hardened AISI 4140 steel (63 HRC) with $\mathrm{Al}_{2} \mathrm{O}_{3}+\mathrm{TiCN}$ mixed ceramic tool, Materials and Design, 2006.

[5] Ramanan.G, Neela Rajan.R, Diju samuel.G, Edwin Raja Dhas.J, Multiple Response Characteristics Optimization of WEDM Parameters for AA7075 composites by Response Surface Grey Relative analysis, International Journal of Mechanical Engineering and Technology. Vol.8, pp.667-676, 2017.

[6] M.A. El-Baradie, I.A. Choudhury, Surface roughness prediction in the turning of high strength steel by factorial design of experiments, Journal of Materials Processing technology, 67, 1997, pp.55-67.

[7] N. Nalbant, H. Gokkaya, G. Sur, Application of Taguchi method in the optimization of cutting parameters for surface roughness in turning, Materials and Design, 2006.

[8] Partha Protim Das Priyank, Kumar Ghadai, M. Ramachandran, KanakKalita, Optimization of Turning Process Parameters by Taguchi-Based Six Sigma, Mechanics and Mechanical Engineering, 21(3):649-656, 2017 